\title{
Influence of bacteria on absorption from the small intestine
}

\author{
By R. Kenworthy, Unilever Research Laboratory, Colworth House, \\ Sharnbrook, Bedford
}

\section{Intestinal morphology and the dynamics of epithelial cell renewal relative to gut function}

The main organ for absorption of dietary nutrients is the small intestine, the functional units being the villus, and the epithelial cell clothing the villus. Since the influence of intestinal bacteria on absorption appears to be mediated through both these components in the normal animal it is necessary to consider briefly the morphology of the intestinal mucosa, and also the dynamics of epithelial cell renewal.

The small intestine of mammals is especially adapted for absorption by its large surface area; it is very long, but its area is increased many times by the plicae circulares, and by the villi. These latter are small projections of the mucus membrane and have a length of $0.5-1.5 \mathrm{~mm}$ (Bloom \& Fawcett, 1962). They cover the entire surface of the mucosa, and are clothed by a simple columnar epithelium. Verzár \& McDougall (1936) state the length of the rat small intestine to be 600 $\mathrm{mm}$, with a surface area of $6726 \mathrm{~mm}^{2}$ excluding villi; with villi the area becomes $45486 \mathrm{~mm}^{2}$, an increase of some sevenfold. Between the bases of the villi, extending down into the lamina propria, are the crypts of Lieberkühn; the epithelial cells referred to arise from division of relatively undifferentiated cells in the crypt, but once division has taken place differentiation is complete relative to eventual function. In the normal animal the intestinal mucosa is in a constant state of renewal, with active proliferation of cells in the crypts followed by their migration up the villi and eventual desquamation from the tips (Leblond \& Stevens, 1948). The time taken for complete replacement of the epithelial lining of the gastrointestinal tract in man is estimated at $3^{-6}$ days (Lipkin, 1965).

However, it appears that the shape of the villus is also important relative to its functional efficiency. Finger-shaped villi are said to 'pump' actively (Verzár \& McDougall, I936) whereas leaf-shaped villi never show any pumping movements; in these latter circular contractions of the muscularis occur which have the effect of squeezing the villi together. Furthermore, striking features of certain malabsorptive states in man are the absence or rudimentary character of the villi and the increased depth of the crypts (Shiner, 1957; Shiner \& Doniach, I960).

It has also been shown in sprue-like conditions that the epithelial cells at the luminal surface are distinctly abnormal (Padykula, Strauss, Ladman \& Gardner, I96I). Their cytoplasm is strongly basophilic, and they are deficient in succinic dehydrogenase, esterase, acid phosphatase and adenosine triphosphatase activities. Padykula et al. (196I) suggest that in sprue the epithelium is proliferating at a rate greater than normal, and the histological appearance of the mucosa is a result of the abnormally high rate of cell loss which is balanced by heightened mitotic activity.

The evidence that villus morphology and cellular differentiation play an important part in intestinal function thus appears conclusive. Is is therefore reasonable 
to suppose that any factor which is likely to have a bearing upon rate of cell division in the crypt, cell migration up the villus, or desquamation from the extrusion zones will have an influence upon absorptive efficiency.

\section{Bacterial component of the small intestine : conventional and gnotobiotic animals compared}

The intraluminal substrate of the intestine is obviously in very close association with the epithelium, and may carry a heavy bacterial load. Table I shows the quantitative and qualitative distribution of microbes in the jejuna and ilea of pigs I day old, I I days old and 30 days old (I week after weaning). It will be seen that

Table I. Quantitative and qualitative distribution of microbes in the small intestine of young pigs (microbial counts $\times 1 \mathrm{1}^{6}$, expressed/g wet content; adapted from Kenwarthy $\mathscr{F}^{\circ} \mathrm{Crabb}, \mathrm{1963)}$

\begin{tabular}{|c|c|c|c|c|c|c|c|}
\hline $\begin{array}{l}\text { Age of } \\
\text { pig } \\
\text { (days) }\end{array}$ & $\begin{array}{l}\text { Intestinal } \\
\text { site }\end{array}$ & $\begin{array}{c}\text { Escherichia } \\
\text { coli }\end{array}$ & Lactobacilli & Clostridia & $\begin{array}{l}\text { Gram- } \\
\text { positive } \\
\text { cocci }\end{array}$ & Yeasts & Total \\
\hline $\mathbf{I}$ & $\begin{array}{l}\text { Jejunum } \\
\text { Ileum }\end{array}$ & $\begin{array}{l}0.05 \\
5.00\end{array}$ & $\begin{array}{l}0.50 \\
6 \cdot 30\end{array}$ & $\begin{array}{r}0.40 \\
10.00\end{array}$ & $\begin{array}{r}0.25 \\
40.00\end{array}$ & $\begin{array}{l}0 \\
0\end{array}$ & $\begin{array}{r}1 \cdot 20 \\
6 I \cdot 30\end{array}$ \\
\hline I I & $\begin{array}{l}\text { Jejunum } \\
\text { Ileum }\end{array}$ & $\begin{array}{r}5.85 \\
17.50\end{array}$ & $\begin{array}{l}400 \cdot 00 \\
200 \cdot 00\end{array}$ & $\begin{array}{r}0.16 \\
50.00\end{array}$ & $\begin{array}{r}10.00 \\
1585.00\end{array}$ & 0 & $\begin{array}{r}411.01 \\
1852.50\end{array}$ \\
\hline 30 & $\begin{array}{l}\text { Jejunum } \\
\text { Ileum }\end{array}$ & $\begin{array}{l}6000 \cdot 00 \\
3000 \cdot 00\end{array}$ & $\begin{array}{r}1000 \cdot 00 \\
50 \cdot 00\end{array}$ & $\begin{array}{l}0.0 \\
0.0\end{array}$ & $\begin{array}{l}0.30 \\
I \cdot 26\end{array}$ & $\begin{array}{l}0.005 \\
0.002\end{array}$ & $\begin{array}{l}7000 \cdot 30 \\
3051 \cdot 26\end{array}$ \\
\hline
\end{tabular}

the total bacterial loading can become extremely high in the small intestine $\left(7 \times 10^{9} / \mathrm{g}\right.$ wet content) particularly after a change of diet. Therefore the composition of the substrate presented to the epithelial surface will be dependent, at least in part, on the metabolic activities of these micro-organisms. Michel (1962) has shown that the microbial flora of the pig intestine is capable of producing from catabolism of amino acids, urea and choline, substances which have a direct pharmacodynamic action. Larson \& Hill ( 1960 ) compared amine production in the ileal content of chlortetracycline-fed pigs with unsupplemented controls. They showed a greater amount and variety of amines in the latter. Spots with $R_{F}$ values corresponding to putrescine, ethanolamine, tyramine and tryptamine were elicited from ileum contents of 22-day-old animals on basal diets. No spots were demonstrated from extracts of ileum contents of chlortetracycline-fed litter-mates. The authors conclude that a reduction in amine and an increased availability of nutrients resulting from the sparing of amino acids contributed to the favourable development of the supplemented group.

This, however, appears to be an oversimplification. We have to consider not only the sparing action, but also two other factors: (I) the effect of the immune response on villus morphology and (2) the possible pharmacological influence of toxic amines, phenols, ammonia, etc. on the epithelial cell. This latter in turn has two implications; by toxic and irritative mechanisms the turnover rate of the epithelium is likely to be increased, leading to distorted villus morphology and following 
on this the cells reaching the extrusion zones will be immature and thus not fully functional.

Relative to these considerations, the work of Gordon \& Bruckner-Kardoss (I96I) and Abrams, Bauer \& Sprinz (I963) is of interest. Gordon \& BrucknerKardoss ( $196 \mathrm{r}$ ) showed that the presence of the flora augments the amount of lamina propria tissue, this effect being particularly clear-cut in the core of the villus. They concluded that the flora-induced increment of the lamina was partly caused by its greater content of reticulo-endothelial cells and possibly by increased hydration of the tissue. Abrams et al. (1963) studied the influence of the normal flora on mucosal morphology and cellular renewal in the ileum of germ-free and conventional mice. In the germ-free mouse the lamina propria consisted of only a sparse stroma, with few lymphocytes and mononuclear cells. In the conventional animal the lamina was expanded by the customary infiltration of lymphocytes, mononuclear cells and plasma cells. The epithelium of the germ-free animal was more regular, the brush border wider, the crypt shallower and the mitotic counts lower; thus there was an apparent shift in favour of the functional compartment with the germ-free status. Furthermore autoradiographic studies of the ileum after administration of tritiated thymidine showed that cellular renewal rates were influenced by the flora. The rate of turnover of the ileal epithelium in the germ-free state was found to be significantly lower than in the presence of the conventional flora.

Our own work on the mucous membrane of gnotobiotic and multicontaminated pigs supports these findings (Kenworthy \& Allen, 1966). Experiments on initially germ-free pigs showed a step-wise degradation of villus morphology with increasing contamination (Pl. I $a-e$ ). In the monocontaminated pig, 5 weeks of age on artificial diet, villi were uniformly symmetrical and classically finger shaped ( $\mathrm{Pl}$. $\mathrm{I} a, b)$; in the duocontaminant ( $\mathrm{Pl}$. I $c$ ) the beautiful uniformity was beginning to be lost; villi became broader at the base and showed evidence of branching. The multicontaminated animals were grossly different $(\mathrm{Pl}$. I $c, d)$; villi were considerably reduced in height, particularly relative to crypt length, and there was much fusing and 'clubbing'. Table 2 shows the various contaminations which were performed, and Table 3 the crypt to villus ratios and mitotic indices of the experimental animals when they were slaughtered 14 days after initial contamination. The diet was standard

Table 2. Contamination of germ-free pigs with micro-organisms (Kenworthy Eे Allen, 1966)

\begin{tabular}{|c|c|}
\hline Pig & Contamination \\
\hline & $\begin{array}{l}\text { Multicontamination by housing in conventional } \\
\text { piggery }\end{array}$ \\
\hline 28 & $\begin{array}{l}\text { Non-haemolytic Escherichia coli (o8:H-). E. coli } \\
\left.\text { 'pathogenic' serotype (oI } 4 \mathrm{I}: \mathrm{K} 85 \text { a,c (B): } \mathrm{H}_{4}\right) \\
\text { added Io days later }\end{array}$ \\
\hline 29 & $\begin{array}{l}E . \text { coli 'pathogenic' serotype (or } 4 \mathrm{r}: \mathrm{K}_{5} \text { a,c (B): } \\
\mathrm{H}_{4} \text { ) only }\end{array}$ \\
\hline 30 & Coagulase negative, Staphylococcus only \\
\hline $3 \mathbf{I}$ & $\begin{array}{l}E \text {. coli 'pathogenic' seroytpe (oI } 4 \mathrm{I}: \mathrm{K} 85 \text { a,c (B): } \\
\left.\mathrm{H}_{4}\right) \text { followed by } E \text {. coli (o8:H-) } 8 \text { days later. }\end{array}$ \\
\hline
\end{tabular}


Table 3. Crypt : villus ratios and mitotic indices in gnotobiotic and multicontaminated pigs (Kenworthy $\mathbb{O}^{\circ}$ Allen, 1966)

\begin{tabular}{|c|c|c|}
\hline $\begin{array}{l}\text { Pig } \\
\text { no. }\end{array}$ & $\begin{array}{l}\text { Crypt : adult } \\
\text { cell ratio }\end{array}$ & $\begin{array}{l}\text { Mitotic figures/I00 } \\
\text { crypt cells }\end{array}$ \\
\hline 25 & $1: 1 \cdot 2$ & $4: 3$ \\
\hline 26 & I : I & 3 \\
\hline 26 (mucous area) & I : I·2 & $5 \cdot 5$ \\
\hline 28 & $1: 3$ & $2 \cdot 1$ \\
\hline 29 & $1: 3.5$ & $I \cdot 5$ \\
\hline 30 & I $: 4$ & $I \cdot 2$ \\
\hline 31 & I $: 3.8$ & $x \cdot 6$ \\
\hline
\end{tabular}

throughout. It will be seen that in the monocontaminants the villus was three to four times longer than the crypt, whereas in the multicontaminants the ratio was about $I: I$.

A characteristic feature of limited contamination was the tall columnar nature and basally situated nucleus of the cells clothing the villi. The cytoplasm of these cells was uniformly acidophilic. The brush border was clearly defined in histological sections stained by haematoxylin and eosin, and the great length of the microvilli was demonstrated by electron microscopy (Pl. $2 a$ ).

In the multicontaminated animals, the epithelial cells on the villi were cuboidal, with a centrally placed nucleus and a tendency to basophilic cytoplasm, even at the tips of the villi. The brush border could not be so clearly defined, and under the electron microscope the microvilli were about one-third the length of those in the gnotobiotic pigs (Pl. $2 b$ ).

Direct physiological experimentation on intestinal function in germ-free animals compared with conventional controls has been carried out by Heneghan ( 1963 ). He showed that the absence of a microbial flora produced a twofold increase in the absorption of $\mathrm{D}$-xylose in germ-free mice as determined by the everted sac technique. The existence of a similar increase was confirmed in germ-free rats by using in vitro and in vivo techniques.

Coupling the foregoing observations with the detailed work of Padykula et al. ( 196 I) already referred to, the evidence for a predominantly adverse effect of microbes on intestinal absorption is very convincing. The question that now arises is whether any particular group of micro-organisms is of particular importance.

\section{Significance of particular bacterial groups}

Some attempts to specifically define those agents which are particularly obnoxious under a given set of conditions (species, type of management and age of affected animal) have already been made. Dubos \& Schaedler (1960) found that mice delivered by Caesarian section and maintained in an environment protected from contact with common mouse pathogens grew more rapidly than conventional controls. Bacteriological studies showed that the 'protected' mice were lacking in Gram-negative lactose fermenters (Escherichia coli); when contaminated with this organism they acquired the characteristics of conventional animals with regard to weight gain on various diets. Eyssen $\&$ de Somer (i 963 ) reported on a malabsorption syndrome in chickens which could be prevented by oral antibiotic 
medication. They were unable to reproduce the whole syndrome in germ-free chicks by various contamination experiments including a mixed flora of thirty-five strains of intestinal bacteria. A partial effect was, however, obtained by contamination with a Gram-positive coccus (Eyssen \& de Somer, i965).

Similar results have been reported by Huhtanen \& Pensack (1964) using a strain of Streptococcus faecalis.

\section{Conclusion}

In conclusion it must be said that although the evidence for a bacterial influence on intestinal absorption appears to be conclusive, the mediating mechanisms are inordinately complex. It is clear that interactions between the various groups of bacteria in the intraluminal substrate are likely to have a bearing upon the biochemical activities of any single species; this is generally accepted. What does not appear to be so generally appreciated however, is the influence of the intraluminal substrate upon the micro-organisms. The effect that dietary change has upon one component ( $E$. coli) of the intestinal flora of young pigs has already been referred to. Similar results are observed relative to dietary changes in sheep and their influence upon Clostridium welchii. In both these instances the implied alteration in metabolism shown by increased growth rate of the micro-organism is accompanied by an increase in its toxicity. The difficulty in experimental reproduction of enteric disease by accepted enteric pathogens is well known to workers in the field of gastroenterology. Thus it is essential to remember that the absorptive organ, the small intestine, is a dynamic physiological entity of which the microbial flora is an integral part. The mucous membrane of the small intestine, the intraluminal substrate and the intestinal microbes are interdependent; they are three components of a system which is in dynamic equilibrium and, in the final analysis, one cannot be considered without reference to the other two.

\section{EXPLANATION OF PLATES}

\section{PLATE I}

(a) Villi, small intestine, monocontaminated gnotobiote (E. coli or $4 \mathrm{I}: \mathrm{K}_{5}$ a,c (B): $\left.\mathrm{H}_{4}\right) . \times \mathrm{I}_{5}$. (Kenworthy \& Allen, r966).

(b) Villi, small intestine, monocontaminated gnotobiote (E. coli or $4 \mathrm{I}$ : $\mathrm{K}_{5} \mathrm{a}$ a,c (B): $\left.\mathrm{H}_{4}\right)$. Haematoxylin and eosin. $X$ r6o. (Kenworthy \& Allen, r 966 ).

(c) Villi, small intestine, duocontaminated gnotobiote (E. coli $\mathrm{OI}_{4} \mathrm{I}: \mathrm{K} 85$ a,c (B): $\mathrm{H}_{4}$ and $\mathrm{o} 8: \mathrm{H}-$ ). Haematoxylin and eosin. $X$ I60. (Kenworthy \& Allen, I966).

(d) Villi, small intestine, multicontaminated pig. $\times 20$. (Kenworthy \& Allen 1966).

(e) Villi, small intestine, multicontaminated pig. Haematoxylin and eosin. $\times$ 160. (Kenworthy $\&$ Allen, 1966).

PLATE 2

(a) Microvilli, monocontaminated gnotobiote (Staph. albus). $\times 30000$ (Kenworthy \& Allen, 1966).

(b) Microvilli, multicontaminated pig. $\times 30000$. (Kenworthy \& Allen, 1966).

\section{REFERENCES}

Abrams, G. D., Bauer, H. \& Sprinz, H. (I963). Lab. Invest. 12, 355.

Bloom, W. \& Fawcett, D. W. (1962). A Textbook of Histology, 8th ed. Philadelphia and London: W. B. Saunders Co. 

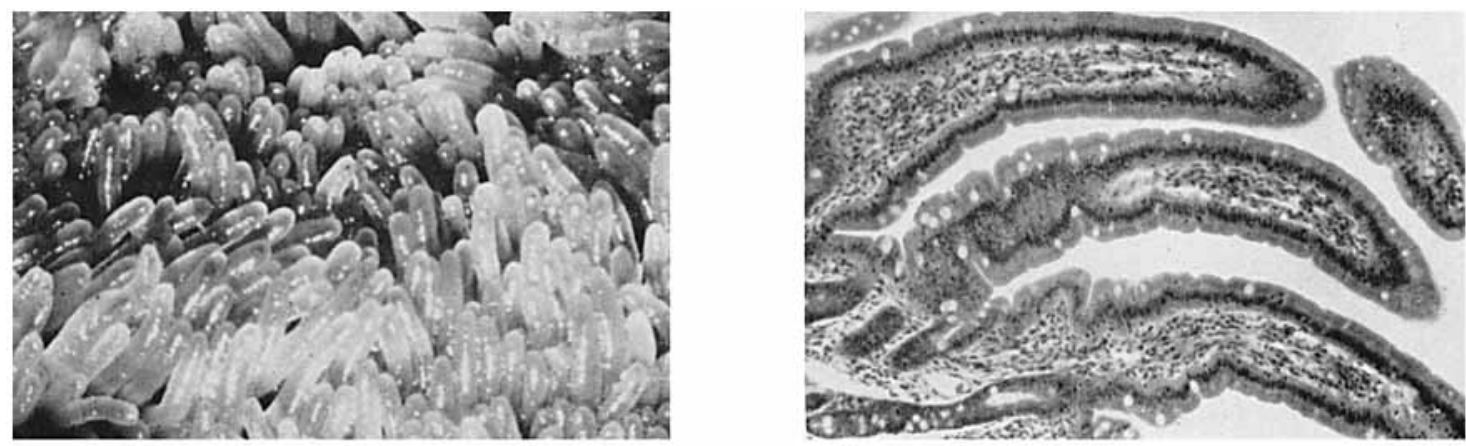

(a)

$(c)$

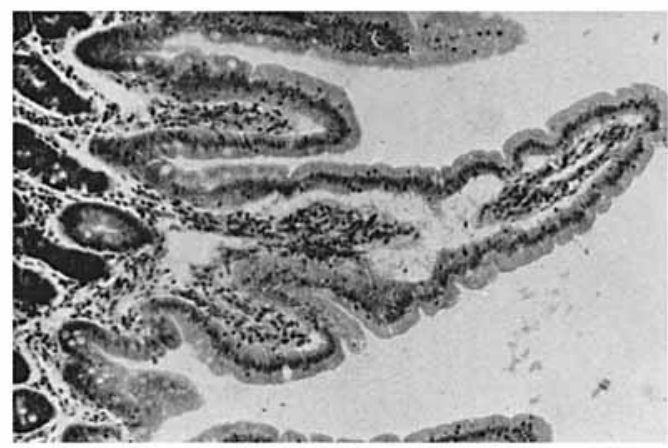

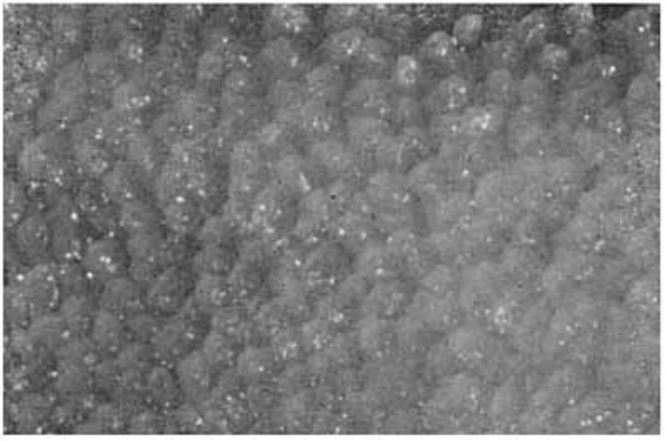

(d)

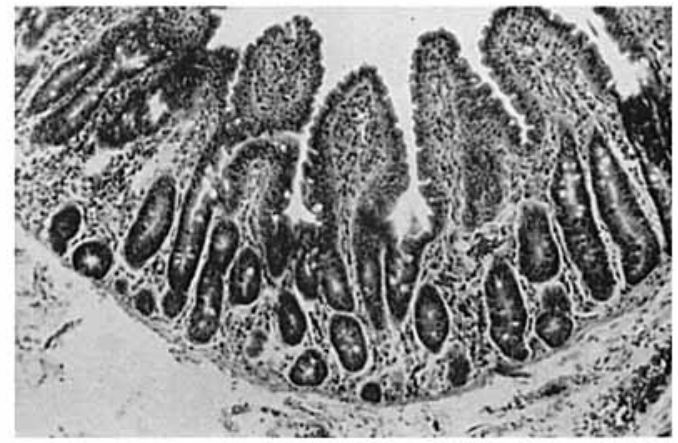

(e)

R. KENWORTHY

(Facing p. 22) 
(a)

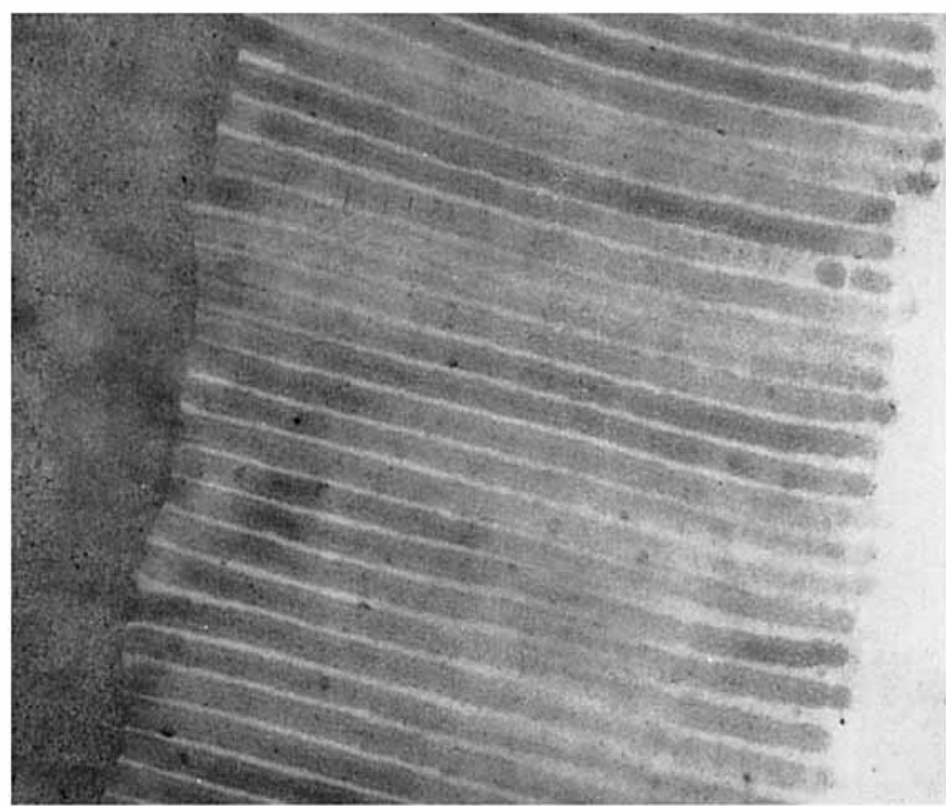

(b)

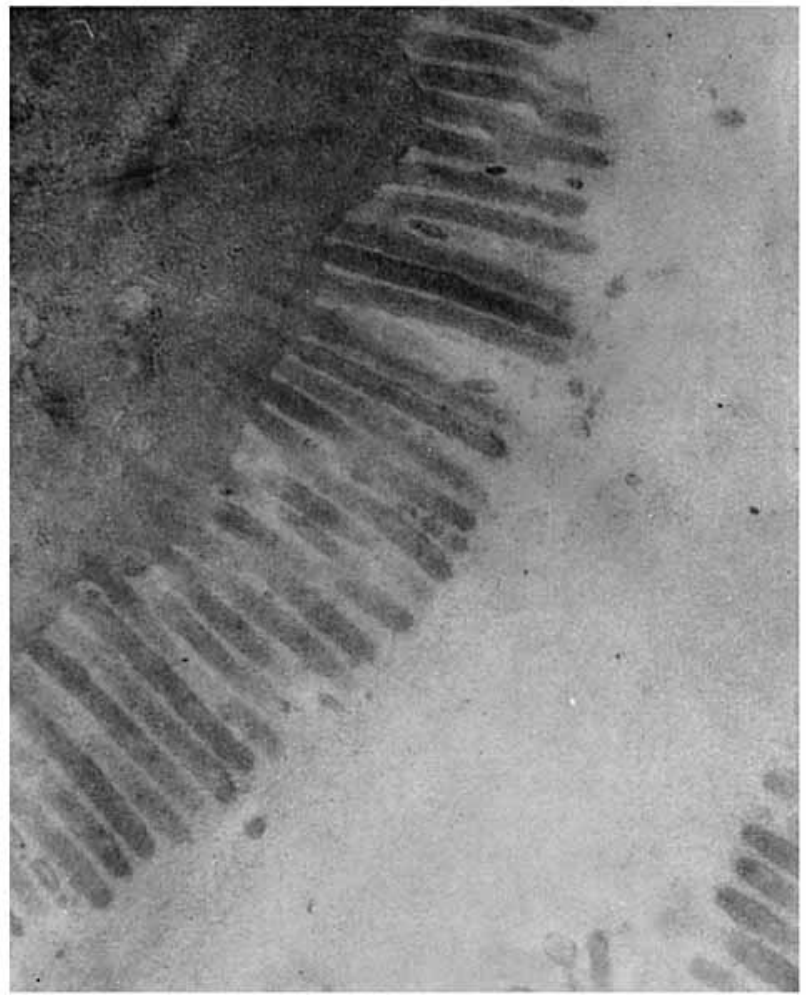

\section{R. KENWORTHY}


Dubos, R. J. \& Schaedler, R. W. (1960). \%. exp. Med. III, 407.

Eyssen, H. \& de Somer, P. (1963). F. exp. Med. 117, 127.

Eyssen, H. \& de Somer, P. (1965). Ernährungsforschung ro, 264.

Gordon, H. A. \& Bruckner-Kardoss, E. (I96r). Acta anat. 44, 2 ro.

Heneghan, J. B. (I963). Am. 7. Physiol. 205, 417.

Huhtanen, C. H. \& Pensack, J. M. (1964). Poult. Sci. 43, 133 I.

Kenworthy, R. \& Allen, W. D. (1966). F. comp. Path. 76, 291.

Kenworthy, R. \& Crabb, W. E. (1963). \%. comp. Path. 73, 215.

Larson, N. L. \& Hill, E. G. (1960). F. Bact. 80, 188.

Leblond, C. P. \& Stevens, C. E. (1948). Anat. Rec. Ioo, 357.

Lipkin, M. (1965). Fedn Proc. Fedn Am. Socs exp. Biol. 24, Part 1, p. ro.

Michel, M. C. (1962). Amino Acides 5, I 57.

Padykula, H. A., Strauss, E. W., Ladman, A. J. \& Gardner, F. H. (196r). Gastroenterology 40, 735.

Shiner, M. (1957). F. Mt. Sinai Hosp. 24, 273.

Shiner, M. \& Doniach, I. (rg60), Gastroenterology 38, 419.

Verzár, F. \& McDougall, E. J. (1936). Absorption from the Intestine. London, New York and Toronto: Longmans, Green and Co.

\section{Absorption of proteins}

\section{By R. B. Fisher, Department of Biochemistry, University of Edinburgh}

Some years ago I reviewed current beliefs concerning the digestion and absorption of protein (Fisher, I954). The view then was that proteins were broken down to amino acids in the intestine and were passed across the mucosa as such into the portal blood.

There seemed to me to be two major objections to this view. The first objection was that all available evidence suggested that the time-course of hydrolysis of protein by alimentary enzymes was at least an order too slow. The second objection was that no one had ever accounted for more than a minority of the protein in the form of amino acids added to the blood stream.

Since that time a great deal of work has been carried out on a number of aspects of these problems. Before I consider how far this work has changed the position I want to try to clear up some general points.

First I want to emphasize the distinction between the two processes ( $I$ ) uptake of substances from the lumen of the intestine and (2) passage of substances from the mucosa into the body fluids. We have got so tied up with the notion that demonstration of active transport requires that we should show transport against a concentration gradient, that we tend to forget that what comes out may be in a different form from what goes in. For instance, when fructose is absorbed from guinea-pig small intestine, a third of it appears on the other side as glucose (Darlington \& Quastel, I953).

Secondly, I want to emphasize the potential multiplicity of means of transport. This is again best illustrated by the facts of carbohydrate absorption. None of us has any doubt of the existence of active absorption of glucose from the intestine. Neither do we doubt the existence in pancreatic secretions of enzymes capable of breaking down starch all the way to glucose. But it is now quite clear from the work 